\title{
BOOK REVIEW: SELEZNEV YU.V. KARTINY ORDYNSKOGO IGA [SCENES OF THE HORDE'S YOKE]
}

\author{
Charles J. Halperin \\ Bloomington, Indiana, USA \\ chalperi@indiana.edu
}

\begin{abstract}
The latest monograph by Iurii Vasil'evich Seleznev of Voronezh State University, Kartiny ordynskogo iga, discusses the social and political interaction of Rus' princes with the Juchid ulus (the Horde) during the thirteenth to fifteenth centuries. By examining trips by Rus' princes to and from the Horde and the amount of time they spent at the Horde, the activities of Rus' princes who became in-laws of the khans by marrying Chingissid princesses, Rus' princely attendance at Horde quriltais (assemblies), how the Rus' princes greeted khans who crossed Rus' territory, Rus' princely service in Horde military campaigns, possible Rus' princely membership in the Horde's Imperial Guard (keshig), the reception of Horde envoys by the Rus' princes and the dispatch of Rus' envoys to the Horde, and the judicial processes that led to the execution of Rus' princes at Sarai or in the Horde's nomadic camp, Seleznev demonstrates conclusively that the Rus' princes had the opportunity to become familiar with Horde military strategy and tactics, Horde ceremonial and ritual, and Horde political culture. However, the question of the extent of Tatar influence on Rus' political institutions and identity remains a difficult one.
\end{abstract}

Keywords: Rus', Horde, Rus'-Tatar relations, quriltai, keshig, Tatar Yoke, Juchid ulus

For citation: Halperin Ch.J. Book Review: Seleznev Yu.V. Kartiny ordynskogo iga [Scenes of the Horde's Yoke]. Zolotoordynskoe obozrenie=Golden Horde Review. 2019, vol. 7, no. 2, pp. 392-400. DOI: 10.22378/2313-6197.2019-7-2.392-400

As a literary conceit Iurii Vasil'evich Seleznev of Voronezh State University structures his latest monograph on Rus'-Tatar relations as the script of a play. He begins with a scholarly Introduction, but this is followed by an Exposition, a Prologue with two scenes, three Acts with five or six scenes apiece, and an Epilogue before returning to scholarly monograph form to conclude with a bibliography $(388-415)^{1}$, two Appendixes, lists of maps and illustrations (413), a list of abbreviations (414), and Indexes of personal (415-431) and geographic (432-436) names. The substantive sections of the book discuss various themes of the relationship of Rus' to the Juchid ulus, most often called the Horde in contemporary Rus' sources, and present both the conclusions of his many previous publications, especially [7], from which he borrows and sometimes revises large excerpts ${ }^{2}$, and analyses of new topics (perhaps anticipated in articles, which I have not consulted). The monograph as a whole thus repeats and expands his conclusions about how subordination to the Horde affected the activities of the Rus' princes during the thirteenth to fifteenth centuries.

\footnotetext{
${ }^{1}$ The Table of Contents refers to the "List of sources and literature" (Spisok istochnikov $i$ litetratury), but the heading on (288) is "Bibliographical List" (Bibliograficheskii spisok), subdivided into "Sources" (Istochniki) (388-391) and "Literature" (Literatura) (397-412).

${ }^{2}$ [7] lacked maps, illustrations, or indexes.
} 
In the "Introduction" (Vvedenie) (4-21) Seleznev questions the common wisdom that Tatar rule turned Rus' into an oriental despotism and its ruler into a tyrant. He suggests that Tatar influence on Rus' institutions was less than is usually believed but on Rus' political culture more than is usually believed. He defines the goal of this monograph as the creation of a static "verbal model" (verbal'noi model') of Rus'-Tatar relations (6).

In the "Exposition: Tatar Subordination" (Ekpozitsiia: tatarskaia nevolia) (2236) Seleznev rejects the term "the Mongol-Tatar Yoke" (tatarskoe igo) to encapsulate the period and system of Tatar sovereignty over Rus' as an anachronism not found in thirteen-fifteenth-century Rus' sources, but still justifies applying the term “yoke' (igo) in place of terms which appear in Rus' sources at different stages of Tatar rule such as nevolia. He also questions the applicability of concepts such as vassalage, protectorate, and ministeriales to connote all the dimensions of Tatar sovereignty as a legal and political system.

In his "Prologue: Obligations to the Tatars" (Prolog: Tatarskoe protory) (3748) Seleznev proposes a periodization schema of Rus'-Tatar relations from 1223 to 1480 before discussing tax obligations in Scene (Kartina) 1 (39-44) and military obligations in Scene 2 (44-47). In the latter he interprets the replacement, at the urging of Prince Alexander Nevskii, of conscription by the baskak system as "the first step toward liberation [of Rus'] from Horde dependence" (47) because it weakened Tatar rule.

“Act 1: Batu's Commandment" (Deistvie pervoe: Batieyeva zapoved') (49-107) derives largely from his previous studies [7, p. 254-302; 6, p. 104-128] and contains five scenes: Scene 1 on departure of Rus' princes to the Horde, Scene 2 on the route they traveled, Scene 3 on what took place in Sarai or at the khan's camp, Scene 4 on the return trip, and Scene 5 on the duration of the trip. It bears repeating that the Rus' princes knew they had to pay courtesy calls at the Horde on the khan's wives and members of the elite, and that the frequency of trips and length of stay at the Horde reflected very sensitively the degree of power that the Horde exercised over the Russian forest zone. Logically, the time Rus' princes spent at the Horde gave them ample opportunity to be influenced by Tatar political culture. Seleznev's observation that the Rus' princes explored the khan's nomadic camp on horseback because no one at the Horde walked around is the kind of social detail that reminds the reader that we are dealing with real people, not just abstractions like "the Horde."

"Act 2: The Land of the Khan and Batu" (Deistvie vtoroe: zemlia kanovi $i$ Batyeve) (108-184) is new, highly original, and very stimulating. Scene 1 discusses visits of the khan to the land of his subjects (108-19), which did not happen often, usually in connection with Tatar campaigns against the western neighbors of Rus'. It was incumbent on the Rus' princes to prepare the roads and if necessary bridges for the transit of the khan and his army and to greet the khan with deference and hospitality bearing gifts and food. When Rus' princes and their retinues joined the Tatar army on campaign, the khan, as sovereign of Rus', enjoyed the right to inspect the Rus' troops.

Scene 2 deals with the Rus' princes as in-laws (ziat') ${ }^{3}$ of the khans (119-135). Marriage to a Chingissid princess gave the Rus' princes privileges but also obliga-

${ }^{3}$ Ziat' means brother-in-law or son-in-law, but a more generic translation as "in-law" better suits this discussion. 
tions. Rus' princes had a consultative voice, but not a vote, at quriltais. Such inlaws ranked at the bottom of the hierarchy of the Chingissid Golden Kin (altan uruk) but above commanders of 10,000 troops (a t'ma) called temniki in the Rus' sources. Seleznev provides a genealogical chart of Rus'-Chingissid intermarriages (136).

Scene 3 discusses Rus' princes at kuriltais (137-145), emphasizing their obligation to attend and their lack of participation in the Horde's decision-making process. Only Prince Fedor Rostislavovich Chermnyi regularly attended quriltais (assemblies), and he was probably the exception.

Scene 4 describes Rus' princes serving their Tatar overlords in warfare (145154). Seleznev infers that Prince Fedor Rostislavovich probably served in the Bulgarian campaign of Nogai, the warlord of the western zone of the Juchid ulus. Seleznev adds that by serving in Tatar armies, Rus' princes and their retinues learned Tatar strategy and tactics as well as military culture.

Scene 5 raises, for the first time to my knowledge in Russian-language historiography on the Rus'-Horde relations, the issue of the service of Rus' princes in the khan's guard (Mongol keshig), an institution founded by Chinggis Khan and known to have existed in the world Mongol Empire. Seleznev recounts the long service sojourns of Rus' princes and their hostage sons at the Horde and infers that they served in the Imperial Guard.

Scene 6 on the reception and dispatch of envoys from and to the Horde (107183 ) is the exception in Act 2 because it is taken largely from [7, p. 240-253], except for its end. Envoys demonstrate the inclusion of Rus' princes in the Tatar political system and the dependence of both Rus' principalities and individual Rus' princes upon the khans. Horde envoys installed Rus' princes on their thrones or summoned them to the khan. Tatar envoys had the right (pravo) in the fourteenth century to loot Rus' settlements to make up tax shortfalls (172).

"Act 3: "And they beheaded him..." (Deistvie tret'e: I otsekosha glavy im...) (185-219) begins with an overview of Rus' princely executions. Fourteen of 109 Rus' princes who traveled to the Horde were executed, one in eight ${ }^{4}$. Seleznev repeats his correlation of Rus' princely executions and the phases of the moon. Five scenes follow, one on each adequately documented execution.

Scene 1 on Prince Mikhail of Chernigov (191-198) explores the mystical and apocalyptic context in which his death occurred. In the prophesies of PseudoMethodius of Patara the last tsar before the End of Days is named Mikhail.

Scene 2 on Prince Roman of Riazan' (199-203) links his dismemberment, a deliberate insult, to accusations of treason.

Scene 3 on Prince Mikhail of Tver' (204-211) brings out its imagery of the Babylonian Captivity of the ancient Hebrews, which was temporary until the Hebrews had repented their sins and been forgiven by God. Mikhail's vita links Khan Uzbek's conversion to Islam to his persecution, at the instigation of the Devil, of Christians in general and Mikhail in particular. Seleznev finds no other instance in which someone cut out the heart of the executed.

${ }^{4}$ [1, p. 89$]$ contains a typographical error: "eleven" executed Rus' princes should be fourteen. $[1$, p. 89-90] prints approximately five lines of text twice. 
Scene 4 on Princes Alexander and Fedor of Tver' (211-216) finds only partial analogies in punishments in the Ilkhanate to the stripping of Alexander naked, to dishonor him, before his execution.

Scene 5 on Prince Dmitrii of Tver' Groznye ochi or Zverinnye ochi (of the Terrible Eyes or Bestial Eyes) (216-218) notes that this is the only case in which we know for a fact that the victim was guilty. Rus' sources admit that Prince Dmitrii did assassinate Prince Iurii Danilovich of Moscow for complicity in the executions at the Horde of Dmitrii's father and brother.

Seleznev concludes this Act (218-219) by declaring that while the accusations against Prince Mikhail of Tver' have some basis in credible evidence, the participation of Rus' princes in conspiracies against the khan is highly problematic. Only the guilt of Prince Dmitrii of Tver' is beyond doubt.

In his "Epilogue" (Epilog) (220-221), which serves in lieu of a "Conclusion" to the monograph, Seleznev variously categorizes the Rus' princes as "governors" (namestniki) of the khans in their own "patrimonies" (otchiny), prince-servitors in the khan's polity (ulusniki, from ulus, the name of steppe nomadic polities of varying size), subjects of the khan, and "officials" (chinovniki) of the Mongol Empire. Although the Rus' princes learned Horde political culture, "Russian Orthodox princes, like all Christianized societies, did not accept the political doctrines of the Mongol Empire. This fact explains the relatively (dostatochno) weak degree of influence of Horde political culture on the development of state institutions within the Russian principalities during the period examined here" (221).

Appendix 1 (222-362) is a list of Rus' princes who visited the Horde between 1242 and 1445, including the purpose of the trip, its chronology, and bibliography. It contains 267 visits by 109 princes and three princesses, for a total of 112 people. This Appendix supersedes its predecessor in [7, p. 313-415], which contained 250 trips by 99 princes and three princesses. The net increase in princes is actually eleven, not ten, because one item of the older list was deleted ${ }^{5}$.

Appendix 2 (363-387) presents data on the reception and dispatch of envoys from and to the Horde. It contains 91 entries. Its counterpart in [7, p. 416-430] contained 84 entries, so Seleznev has added seven items ${ }^{6}$.

Kartiny ordynskogo iga makes a significant contribution to our knowledge of the social and political history of both Rus' and the Juchid ulus, and of the intense and complex relations between Rus' and the Tatars during the thirteenth to fifteenth centuries. Its imaginative structure facilitates raising new questions and exploring new themes. To be sure, as a result of his thematic acts and scenes Seleznev sometimes quotes passages from the sources more than once, but that is forgivable. While legitimately questioning the still widespread perception that blames the Tatars for turning Rus' into an authoritarian state with a hypertrophic governmental apparatus, Seleznev continues to demonstrate from the Rus' sources that it is impossible to understand Rus' history during the Tatar period without taking into account Rus'-Tatar relations, even if disagreements over the importance of different aspects of Tatar influence continue to exist. Seleznev also deserves praise for never once demeaning the Tatars as zakhvatchiki (predators). Objective

${ }^{5}$ Old list Table no. 1 was eliminated; the new entries in the new list are Tables no. 2, 6, 24, $40,50,61,89,94,107,111,112$. On Table no. 102 (350) the name of the prince is not in bold type.

${ }^{6}$ The new items are no. $6,19,31,52,72,89,90$. 
scholarship has no space for such anachronistic pejorative terminology. The fullpage color maps and illustrations greatly enhance Seleznev's presentation. Four illustrations (the fifth is the genealogical chart) are miniatures from the Illustrated Chronicle Compilation (Litsevoi letopisnyi svod) from the second half of the sixteenth century. Unfortunately Seleznev did not take advantage of the opportunity to comment on their depiction of the Tatars, which paints them as identical to Rus'.

Because it would be impossible here to comment on all of the issues discussed in Kartiny ordynskogo iga, I will examine only selectively several of Seleznev's conclusions ${ }^{7}$.

(Introduction) Seleznev does not repeat here his recent criticism elsewhere of those Russian historians who disregard all evidence of Rus' subordination to the Horde, such as paying taxes, supplying recruits, making obeisance in person first to the Great Khans in Qaraqorum and then to the khans of the Horde, in order to insist that the Rus' principalities were independent [6, p. 8, 12-22].

The phrase "the Tatar Yoke" is not only an anachronism, it is of foreign provenance. It originated in Latin in the first half of the sixteenth century, in 1521 in Maciej z. Miechowa's Chronicum Polonum [4, p. 241] and reappeared in 1575 in Daniel Printz's Moscovia ortus, et progressus [5, p. 244-245]. It did not appear in Slavic until the second half of the seventeenth century in Innokentii Guizel's Synopsis and slightly later in Andrei Lyzlov's Skifskaka istoriia [Scythian History] [2, p. 168-169], long before its use in Radishchev, the earliest Russian text cited by Seleznev. Radishchev almost certainly found the phrase in the Synopsis, which was very popular in eighteenth-century Russia.

(Prologue) Seleznev's first period of Rus'-Tatar relations (37-39) begins with 1223 and runs to 1241 , so it includes 1224 to 1236 , when the Tatars were entirely absent from Eastern Europe. It might have been better, following Seleznev's theatrical conceit, to call the Battle on the River Kalka a prologue, and let 1237-1274 stand alone as the period of conquest. It seems clear that neither Rus' nor the Tatars understood the significance of the Stand on the Ugra River in 1480 at the time. It might therefore be more instructive to continue the last period of Rus'-Horde relations to 1502 when the Great Horde was destroyed. I leave to others the problem of reconciling the changing nature of Rus'-Tatar relations reflected in Seleznev's periodization schema, a diachronic analysis, with the static nature of his "verbal model," synchronic analysis.

(Prologue, Scene 1) Although Seleznev makes superb use of sources (in Russian translation) from the world Mongol Empire and its successor states, including the "Secret History of the Mongols" and texts from the Yuan dynasty in China and the Ilkhanate in Iran, he continues not to utilize Western-language scholarship on such issues as Mongol taxation.

(Prologue, Scene 2) When the Tatars ceased conscripting Rus' into military service remains very unclear because the Rus' sources do not provide any unambiguous evidence of such conscription at all. Moreover, that Rus' princes and the retinues began performing military service in Tatar campaigns does not preclude the simultaneous continuation of conscription. That Prince Alexander Nevskii "persuaded" the Horde in 1262 to abandon conscription may be too imaginative an interpretation of

\footnotetext{
${ }^{7}$ Each comment is preceded in parentheses by a cross-reference the section of the text to which it pertains.
} 
the Rus' sources. Some historians, moreover, believe that the actual purpose of Cholkhan's "visit" to Tver' in 1327, once we disregard the fantastic motives ascribed to him in Rus' sources, was to recruit conscripts for the Horde's ongoing war with the Ilkhanate. Seleznev does not refer to Chinese sources enumerating Rus' regiments in China to shed light on Juchid conscription of Rus', which is highly relevant unless we believe that Rus' peasants volunteered to serve in the Mongol army thousands of miles from their homes. That the Horde's abandonment of Rus' conscription, like the shift from on-site administration by baskaks to absentee envoys (posoly) and viceroys (darugi), reflected Horde weakness does not sound convincing; both changes, apparently, took place when the Horde was supposedly at its zenith under Khan Uzbek. Both changes strike me as tactical reflections of the relative unimportance of the Russian forest zone to the Horde, whose military strength derived from Tatar nomads and whose wealth derived from international trade. Given the ambivalent Rus' perception of the concept of the Tatar sovereignty, which Seleznev acknowledges, it does not strike me as helpful to describe the putative termination of conscription in 1262 as a step toward "liberation" of Rus' from Horde "dependence." The events of 1327 attest that Tatar authority over Rus' was hardly compromised by the revision of its administrative structure.

(Act 2, Scene 1) One might interpret the rarity of "visits" by the khans to Rus' territory - and then only when on campaign against western neighbors of Rus' such as Poland, Lithuania and Hungary - as evidence that Rus' was only of peripheral importance to the Horde and that the Horde rule over Rus' was sufficiently stable, despite riots and rebellions, that it did not require a khan's presence to maintain control until Tokhtamysh in 1382. Khan Uzbek did not need to travel to Moscow or Tver' to bolster failing Horde authority.

(Act 2,Scene 2) It may be misleading, or at least inappropriate, to present Rus' in-law princes as having consultative-only votes at Tatar quriltais. The Juchid ulus, like the Mongol Empire before it and other coexisting Mongol successor states, was hardly a constitutional regime in which consultative and decision-making authority were clearly distinguished. Medieval Mongol states functioned according to custom, and quriltais pretended to reach unanimous decisions by consensus even when debate descended into civil war. Seleznev is certainly correct that Rus' princes did not participate in the formulation of Horde policy toward Rus', and he deserves credit for raising the issue of Rus' presence at quriltais, if only as loyal subjects eagerly awaiting the decisions of their betters. The question of who attended, rather than who had the "right" to attend, quriltais deserves further research.

(Act 2, Scene 5) The possibility of Rus' enrollment in the Horde's Guards is absolutely fascinating. The problem is simply that as far as I know there is no reliable evidence that the Juchid khans has a keshig. However plausible such an assumption, it remains, nevertheless, an assumption. Earlier Seleznev argued that historians have to assume that the Horde had a Guard, "perhaps" what the Rus' sources call the "household" or "court" (dvor) of the khan [6, p. 58]. Yet the Rus' principalities had "courts" but did not have a comparable keshig, so historians do not have to assume that the Horde had a Guard. The military service of Rus' princes in Horde campaigns and the presence of Rus' princely sons or heirs as hostages in the Horde, notably under Tokhtamysh, cannot constitute direct evidence of their membership in the Horde's keshig unless and until we can establish that such an 
institution existed. Neither military service nor hostages necessarily required integration into an imperial guard.

(Act 2, Scene 6) Certainly Tatar officials, like the Horde itself, thought it had the right to loot any regions of Rus' that failed to meet its tax allocation, but it is doubtful that the Rus' princes thought so, and certainly the Rus' chroniclers did not think so. The Rus' chronicles describe such actions as a great evil (zlo) and described the result as hardship (tiagost') and oppression (nasilie). Confiscation of property of tax evaders and removal from their thrones of Rus' princes who failed to deliver the tribute (vykhod) in full might (see Prince Mikhail of Tver') be authorized, but I think Seleznev's formulation goes too far.

(Act 3, Scenes 1, 3) Seleznev does not comment that the imagery of the Babylonian Captivity could not develop until the apocalyptic response to the Tatars had worn off. If the Apocalypse was near, there would hardly be time for the temporary captivity of the Rus' to expire. Rus' sources articulated multiple intellectual reactions to the Tatar incursions, all of them infused with biblical and scriptural language and concepts.

(Act 3, Scene 3) Seleznev appreciates that the accounts of Tatar executions of Rus' princes sometimes reflect hagiographic motifs and literary etiquette; such details should properly be considered fictitious. Deciding which cliches are reliable offers room for disagreement. The narration of the death of Prince Mikhail of Tver', sainted as a martyr, recounts that a man named Romanets cut out Mikhail's heart. Seleznev finds no analogy to this means of capital punishment in Mongol juridical practice (211); I suspect this is because it is a sensationalist fiction on the part of the Rus' author of Mikhail's vita.

(Epilogue) The multiple terms Seleznev adduces to describe the relationship of the Rus' princes to the Horde reflect the ambiguities of that relationship. The term "vassal" probably better reflects the dimensions of that relationship than "governors." Equating a Rus' prince who swore loyalty to the khan even to an ethnic East Slav who served as a baskak strikes me as misleading. No Rus' of any status, let alone a prince, served as an official of the Horde in Sarai or the khan's nomadic camp. The very concept of chinovnichestvo, bureaucrats in a bureaucratic administrative structure, seems out of place in medieval Rus', so calling the Rus' princes "officials" simply compounds anachronisms. Distinguishing political theory from practice is complicated by the absence of political theory in Rus'. Even in the fourteenth century when Muscovy imposed upon subordinated Rus' princes the obligation not to "know" the Horde, that is to carry on independently diplomatic contacts with the khan, those subordinate princes often did so anyway, and even if obeyed, that injunction did not necessarily preclude pursuing political contacts with polities - such as Lithuania - other than the Horde.

Seleznev at least raises the issue of comparing Rus' relations to the Horde with those of other Christian states toward the Mongol Empire and its successor states, an issue that has not received anything approaching adequate study. We may discard evidence concerning Nestorian Christian societies in the steppe from consideration even if they were sedentarized or partially sedentarized; their differences from agricultural forest Rus' are so great as to invalidate comparative analysis. The Orthodox polities of Armenia and Georgia, however, vassals (for the sake of argument) of the Ilkhanate, can provide a standard of comparison. Seleznev does utilize 
Armenian and Georgian chronicles as sources. Invocations of the apocalypse in labeling the Mongols the peoples of God and Magog, for example, appear in Armenian sources as they did in Rus' sources; in both as well non-Christian conquest constitutes divine punishment for Christian sins. Seleznev writes that Rus' and other Christians did not accept the "political doctrines" of the Mongol Empire. Yet I would propose that the Rus' accepted one major Mongol "political doctrine," indeed the major political doctrine of the Mongol Empire, namely the principle of Chingissid legitimacy, and exploited that doctrine in their depictions of the nonChingissids Mamai, Edigei and Timur. I know of nothing comparable in Armenian or Georgian sources.

(Epilogue) Seleznev recognizes Rus' familiarity with Horde political culture and military strategy and tactics, but neither in this monograph nor in any of his previous monographs on Rus'-Tatar relations has he addressed the evidence of Tatar influence on Rus' "state institutions," specifically Muscovite institutions, not just military but especially financial, from the fourteenth to sixteenth centuries, admittedly subjects of sometimes heated disagreement among western historians. Whether sixteenth-century Muscovy considered itself a successor state of the Juchid ulus has generated considerable discussion but no consensus among specialists inside as well as outside Russia has appeared. Of course Seleznev would need another book to explore this issue properly but lacking that, his conclusion, right or wrong, lacks argumentation and evidence, and appears to be a glib obiter dictum inconsistent with the scrupulously documented conclusions that make Kartiny ordynskogo iga so valuable.

In conclusion, the scholarly level of Iurii Seleznev's Kartiny ordynskogo iga equals that of his previous publications, the highest praise to which it might aspire. It should find a wide audience among specialists in medieval Rus' and Tatar history.

\section{REFERENCES}

1. Halperin Ch.J. Iu.V. Seleznev's Contribution to the Study of the Juchid ulus. Zolotoordynskoe obozrenie=Golden Horde Review. 2014, 2(4), pp. 74-94.

2. Halperin Ch.J. "The Tatar Yoke and Tatar Oppression". Halperin, Russia and the Mongols Slavs and the Steppe in Medieval and Early Modern Russia. Victor Spinei and George Bilavschi, ed. Bucharest: Editura Academiae Romane, 2007, pp. 168-181.

3. Halperin Ch.J. Review of Seleznëv. Russkiia kniaz'ia pri dvore khanov Zolotoi Ordy. Jahrbücher für Geschichte Osteuropas, V.6, no. 4. 2109, pp. 682-684.

4. Keenan E.L. Ivan III, Nikolai Karamzin, and the Legend of the "Casting Off of the Tatar Yoke" (1480). Chester Dunning, Russell Martin, and Daniel Rowland, ed. Rude and Barbarous Kingdom Revisited: Essays in Russian History in Honor of Robert O. Crummey. Bloomington, IN: Slavica Publishers, Inc., 2008, pp. 237-251.

5. Ostrowskii D Muscovy and the Mongols. Cross-cultural influences on the steppe frontier. Cambridge: Cambridge University Press, 1998. 329 pp.

6. Seleznëv Iu. Russkiia kniaz'ia pri dvore khanov Zolotoi Ordy [Russian princes at the Court of the khans of the Golden Horde]. Moscow: Lomonosov, 2017. 272 p.

7. Seleznev Iu.V. Russkie kniaz'ia v sostave praviashchei elity Dzhuchieva ulusa v $X I I I-X V$ vekakh [Rus' Princes as Members of the Ruling Elite of the Juchid ulus from the thirteenth to the fifteenth centuries]. Voronezh: Tsentral'no-Chernozemskoe knizhnoe izdatel'stvo, 2013. $472 \mathrm{p}$. 
8. Seleznev Yu.V. Kartiny ordynskogo iga [Scenes of the Horde's Yoke]. Voronezh: Izdatel'skii dom Voronezhskogo gosudarstvennogo universiteta, 2017. $437 \mathrm{p}$.

About the author: Charles J. Halperin - PhD (History), Independent scholar, Freelancer (vneshtatnyi sotrudnik), Indiana University (Bloomington, Indiana, USA). E-mail: chalperi@iu.edu

\title{
РЕЩЕНЗИЯ НА КНИГУ: СЕЛЕЗНЕВ Ю.В. КАРТИНЫ ОРДЫНСКОГО ИГА
}

\author{
Чарльз Джс. Гальперин \\ Индианский университет \\ Блумингтон, штат Индиана, США \\ chalperi@indiana.edu
}

В новейшей монографии Юрия Васильевича Селезнева из Воронежского государственного университета, «Картины ордынского ига», обсуждается социальное и политическое взаимодействие русских князей с Улусом Джучи (Золотой Орды) в XIII-XV вв. Изучая поездки русских князей в Орду и из Орды, количество времени, которое они провели в Орде, деятельность русских князей, оказавшихся в свите ханов, выйдя замуж за дочерей Чингисидова рода, присутствие русских князей на курултайах в Орде, торжественный прием князьями ханов, пересекавших территорию Руси, княжеское служение в военных действиях Орды, возможное княжеское членство в Имперской гвардии Орды (кешиг), прием посланников орды русскими князьями и посылка русских посланников в Орду, и судебные процессы, которые привели к казни русских князей в Сарае или в кочевом лагере Орды, Селезнев убедительно доказывает, что русские князья имели возможность ознакомиться с военной стратегией и тактикой Орды, ордынской церемонией и ритуалами, а также политической культурой Орды. Однако вопрос о степени влияния татар на политические институты и идентичность России до сих пор остается сложным.

Ключевые слова: Русь, Орда, русско-татарские отношения, кешиг, татарское иго, улус Джучи

Для цитирования: Halperin Ch.J. Book Review: Seleznev Yu.V. Kartiny ordynskogo iga [Scenes of the Horde's Yoke] // Золотоордынское обозрение. 2019. T. 7, № 2. C. 392-400. DOI: 10.22378/2313-6197.2019-7-2.392-400

Сведения об авторе: Чарльз Гальперин - PhD (история), независимый исследователь, внештатный сотрудник, Индианский университет (Блумингтон, штат Индиана, США). E-mail: chalperi@iu.edu 